\title{
Characterization and Mass Spectrometry Analysis of Aminopeptidase N from Pseudomononas putida Lup
}

\author{
URSZULA JANKIEWICZ1, MARIA SWIONTEK-BRZEZINSKA², EWA BEATA GÓRSKA \\ and PAWEE, KOWALCZYK ${ }^{3}$ \\ ${ }^{1}$ Warsaw University of Life Sciences - SGGW, Department of Biochemistry, Warsaw, Poland \\ ${ }^{2}$ Department of Environmental Microbiology and Biotechnology, Institute of Ecology and Environmental Protection \\ Nicolaus Copernicus University, Torun, Poland. Warsaw \\ ${ }^{3}$ University of Life Sciences - SGGW \\ Autonomous Department of Microbial Biology Warsaw, Poland
}

Submitted 20 August 2012, revised 6 May 2013, accepted 19 September 2013

\begin{abstract}
An intracellular aminopeptidase $\mathrm{N}$ synthesized by Pseudomonas putida Lup was purified and characterized. The approx. 150-fold purified enzyme showed highest activity against A- $\beta$-naphthylamide at pII 7.5 and at temperature $40^{\circ} \mathrm{C}$ and was $100 \%$ thermostable for 240 min at $40^{\circ} \mathrm{C}$. P. putida lup aminopeptidase $\mathrm{N}$ is a monomer with molecular mass approx. $99 \mathrm{kDa}$ determined by SDS-PAGE and gel permeation chromatography. The enzyme has broad substrate specificity, but is the most active against protein substrates with $\mathrm{N}$-terminal alanine and arginine. The activity of $P$. putida Lup aminopeptidase $\mathrm{N}$ is strongly inhibited in the presence of specific metallopeptidase inhibitors and is partly recovered in the presence of $\mathrm{Zn}^{2+}$ and $\mathrm{Co}^{2+}$ ions. $\mathrm{Co}^{2+}, \mathrm{Mg}^{2+}$ and $\mathrm{Ca}^{2+}$ ions increased the activity of the enzyme. Moreover, the enzyme was inhibited by inhibitors of cysteine enzymes. Analysis of fragments of the amino acid sequence of the purified enzyme demonstrated high similarity to PepN of Pseudomonas putida GB-1.
\end{abstract}

Ke y word s: Pseudomonas putida, aminopeptidase N, purification of enzymes

\section{Introduction}

Peptidases perform several significant functions in both eukaryotic and prokaryotic organisms. Intracellular peptidases are involved in processes such as splitting off signal peptides from newly synthesized proteins, activation of inactive precursors, inactivation of regulatory proteins and degradation of damaged peptides. Extracellular peptidases can be toxins and virulence factors, whereas others demonstrate low specificity and participate in the breakdown of proteins in the environment to short peptides or single amino acids, which can then be taken up and utilized by the cell (Addlagatta et al., 2006; Jankiewicz and Bielawski, 2003). An important role in cellular protein metabolism in both eukaryotic and prokaryotic organisms is played by aminopeptidases N (APN, EC 3.4.11.2). APN found in living cells is a common exopeptidase with broad substrate specificity.

Mammalian aminopeptidases $\mathrm{N}$ are membrane enzymes that carry out diverse physiological functions, such as receptors for corona- and other human viruses. They also participate in angiogenesis and stimulation of tumor growth and regulation of blood pressure (Kumar et al., 2009). The role of these exoproteases in physiological processes of the host justifies intensive studies on these enzymes and their inhibitors. In bacteria, aminopeptidases $\mathrm{N}$ occur in the cytosol where they participate in ATP-independent protein metabolism and play principal role in the maturation, activation and final stage of peptides hydrolysis to single amino acids (Addlagatta et al., 2006; Lazdunski et al., 1975). Bacterial APN in particular are the main intracellular enzymes releasing $\mathrm{N}$-terminal alanine from protein substrates.

APN belong to the zinc-dependent metallopeptidases, grouped, according to the Merops classification, into family M1 included in the Gluzincin superfamily (thermolysin-like peptidases). All of these enzymes are metallopeptidases with a single zinc ion in the active center (Hooper, 1994; Rawlings and Barrett, 1993). APN have a characteristic conservative $\mathrm{Zn}$-binding $\operatorname{HEXXH}(\mathrm{X})_{18} \mathrm{E}$ motif, in which a $\mathrm{Zn}$ ion is coordinated by two histidine residues and distal glutamic acid. The glutamate next to the first $\mathrm{Zn}^{2+}$-binding histidine in the HEXXH motif is essential for water hydrolysis of

* Corresponding author: U. Jankiewicz, Department of Biochemistry, Warsaw University of Life Sciences, Poland; phone.: +48 22 5932560; fax +48 22 5932578; e-mail: urszula_jankiewicz@sggw.pl 
peptide bond and subsequent release of the substrate (Kumar et al., 2009; Peer, 2011). The structure of the active center has been studied in detail for the APN of the gram-negative bacterium Escherichia coli. It has been found that structurally it exhibits strong similarity to thermolysin. The APN of E. coli, which is composed of 870 amino acids, contains four domains, and the active center is located in domain II, encompasing amino acids residues from 194 to 443 (Matthews, 1988). There are also reports in the literature suggesting the presence of two active centers in APN, one responsible for aminopeptidase activity and one for endopeptidase activity (Chandu et al., 2003). However, more recent data rule out this hypothesis (Addlagatta et al., 2006). They are enzymes with broad substrate specificity, showing highest activity against protein substrates with the alkaline amino acid residues: $\mathrm{R}$ and $\mathrm{K}$ or hydrophobic ones, e.g. A, L, M, at the N-terminus (Chandu and Nandi, 2003; McCaman and Villarejo, 1982).

The objective of the described studies was to purify, identify and characterize the intracellular aminopeptidase synthesized by a strain of the bacterium Pseudomonas putida.

\section{Experimental}

\section{Materials and Methods}

Biological materials. A strain of bacteria synthesizing an intracellular aminopeptidase $\mathrm{N}(\mathrm{ApN})$ was isolated from the rhizosphere of winter wheat cultivated in a field in the eastern part of Poland. Bacteria were isolated using King B medium (King et al., 1954). Identification of the strain selected for further studies was based on biochemical and morphological traits (Holt et al., 1994). The identity of the strain was confirmed by $16 \mathrm{~S}$ rRNA gene sequence analysis. Amplification of 16S rRNA gene was accomplished using universal primers $27 \mathrm{~F}$ and $1492 \mathrm{R}$ (Watanabe et al., 2001). The template in the reaction was genomic DNA isolated from bacterial cells in late logarithmic stage of culture, using a Genomic DNA Purification Kit (Fermentas). The purified PCR product was sequenced in the DNA Sequencing and Oligonucleotides Synthesis Laboratory at IBB PAS (Warsaw, Poland). The obtained nucleotide sequences were compared with those deposited in the available data bases GenBank/EMBL/DDBJ using the program BLAST. The obtained $16 \mathrm{~S}$ rRN $\Lambda$ gene sequence was deposited in the DDBJ database with access number AB667905.

Composition of culture medium, growth conditions and preparation of enzyme extract. The liquid growth medium used was a mineral medium according to Bassalik, composed of: $0.03 \% \mathrm{~K}_{2} \mathrm{PO}_{4} ; 0.03 \% \mathrm{KH}_{2} \mathrm{PO}_{4}$; $0.05 \% \mathrm{MgSO}_{4} ; 0.05 \% \mathrm{NaCl}$ and $0.0015 \% \mathrm{FeCl}_{3}$, supple- mented with $1.5 \%$ tryptone, $0.25 \%$ yeast extract and $0.3 \%$ glucose. The $\mathrm{pH}$ of the medium was adjusted prior to autoclaving to 7.0 .

Bacteria were grown for $48 \mathrm{~h}$ with shaking at $120 \mathrm{rpm}$ and temperature $28^{\circ} \mathrm{C}$. Growth of bacteria was monitored by following $\mathrm{OD}_{600}$. After appropriate culture time the bacteria were spun down $(12000 \times \mathrm{g}, 20 \mathrm{~min})$ and the bacteria in the pellet, after discarding the supernatant, were washed twice in Tris-HCl buffer, $\mathrm{pH} 8.5$ and disrupted by sonication. The clear intracellular protein extract obtained after centrifugation was used as the preparation for purification of the aminopeptidase.

Enzymatic activity. Aminopeptidase activity was determined using synthetic amino acid derivatives of $\beta$-naphthylamide. The incubation mixture consisted of: enzyme preparation, 0.05 M Tris-IICl buffer, pH 7.5 and substrate in final concentration $1 \mathrm{mM}$. The reaction was conducted for 30 minutes and then terminated by the addition of $0.1 \%$ solution of diazo salt of o-aminotoluene (Fast Garnet GBC), dissolved in $1 \mathrm{M}$ acetate buffer, pH 4.2 with the addition of $10 \%$ Tween 20 . The absorbance of the colored product was determined photometrically at $525 \mathrm{~nm}$. Absorbance readings were calculated to give $\mu$ mole product formed using a standard curve prepared for five concentrations of $\beta$-naphthylamine.

One unit of activity was defined as one $\mu$ mol naphthylamine formed in 1 min reaction time.

Purification of the enzyme. All purification stages (except for HPLC chromatography) were carried out at $4^{\circ} \mathrm{C}$. Fractionation with ammonium sulfate was performed by salting out the enzyme preparation in the first stage of fractionation to $35 \%$, and in the second to $85 \%$ saturation with ammonium sulfate. The protein deposit was dissolved in $20 \mathrm{mM}$ Tris- $\mathrm{HCl}$ buffer, pH 7.8 and dialyzed overnight against the same buffer. The obtained preparation was subjected to low pressure ion-exchange chromatography on anionite cellulose DE $\Lambda$ E 52.

Prior to chromatography, the column was equilibrated with $20 \mathrm{mM}$ Tris-HCl buffer, $\mathrm{pH} 7.8$. Protein was eluted with linear $\mathrm{NaCl}$ gradient from 0 to $0.5 \mathrm{M}$. Fractions with highest enzymatic activity were pooled and dialyzed for 12 hours against $20 \mathrm{mM}$ Tris-HCl buffer, $\mathrm{pH}$ 7.8. The next stage of purification involved preparative electrophoresis in BIO-RAD Model 491 Prep Cell apparatus, with $7.5 \%$ separating gel and $4 \%$ concentrating gel, at constant voltage of $240 \mathrm{~V}$. Separation was in $25 \mathrm{mM}$ Tris - $192 \mathrm{mM}$ glycine buffer, $\mathrm{pH}$ 8.3. Proteins were eluted from elution chamber with $25 \mathrm{mM}$ Tris$\mathrm{HCl}, \mathrm{pH}$ 7.8. Fractions showing highest alanyl aminopeptidase activity were used for the next purification step, i.e. high pressure ion-exchange chromatography HPLC. The enzyme solution was applied to ProteinPak Q 8HR column, which was first equilibrated with $15 \mathrm{mM}$ Tris-HCl buffer, $\mathrm{pH} 7.8$. Elution was with linear $\mathrm{NaCl}$ gradient from 0.2 to $0.5 \mathrm{M}$. Fractions with highest 
aminopeptidase activity were used for enzyme characterization and MS analysis experiments.

Determination of protein content. Measurements of protein concentration at all stages of the study were made using the Bradford method (1976). Absorbance values were converted to $\mu \mathrm{g}$ protein using a standard curve plotted for five concentrations of bovine serum albumin.

Electrophoretic separations and detection of aminopeptidase activity. Electrophoresis under native and denaturing conditions was according to the procedure described by Laemmli (1970). The protein bands were visualized using Coomassie Brilliant Blue R-250. Aminopeptidase activity in polyacrylamide gel following electrophoretic separation was detected after incubation of the gel in $1 \mathrm{mM}$ solution of the substrate in Tris-HCl buffer, $\mathrm{pH}$ 7.5.

Determination of molecular weight of the enzyme. The molecular weight of the analyzed enzyme was determined by SDS-PAGE and in the course of gel filtration on a Sephadex G-200 column. The column was calibrated using the following standard proteins: Alcohol dehydrogenase $(150 \mathrm{kDa})$, bovine albumin $(67 \mathrm{kDa})$, ovalbumin $(44 \mathrm{kDa})$, carbonic anhydrase $(29 \mathrm{kDa})$ and cytochrome C (12.4 kDa). The void volume of the column (Vo) was determined using dextran blue.

Characterization of the properties of purified enzyme. The optimum $\mathrm{pH}$ was determined in a range of 5.0-9.0. The buffer systems used were: $50 \mathrm{mM}$ Britton-Robinson buffer for the $\mathrm{pH}$ range of 5.0-9.0 and $50 \mathrm{mM}$ Tris-HCl buffer for the $\mathrm{pH}$ range of 6.8-8.5. The optimal temperature was determined in the range from 25 to $55^{\circ} \mathrm{C}$. Thermal stability was determined after 1,2 , 3 and $4 \mathrm{~h}$ preincubation of the enzyme at temperatures: 40,45 and $50^{\circ} \mathrm{C}$.

Determination of Michaelis-Menten constants. The substrate affinities were determined in the presence of those substrates with which high enzymatic activity (over $60 \%$ compared to $\Lambda$ - $\beta$-naphthylamide activity) was observed; the final concentration of the substrates in the reaction mix was from 0.015 to $1.5 \mathrm{mM}$. The $\mathrm{Km}$ value was determined using the graphical LineweaverBurk method.
The effect of metal ions on activity was determined following preincubation of the enzyme for $30 \mathrm{~min}$ at $4^{\circ} \mathrm{C}$ in the presence of divalent metal ions $\left(\mathrm{Mg}^{2+}, \mathrm{Mn}^{2+}\right.$, $\left.\mathrm{Co}^{2+}, \mathrm{Ca}^{2+}, \mathrm{Cu}^{2+}, \mathrm{Zn}^{2+}, \mathrm{Cd}^{2+}, \mathrm{Pb}^{2+}\right)$ in final concentration of 0.1 and $1.0 \mathrm{mM}$, after which the substrate was added and the residual activity tested.

In order to study the effect of specific inhibitors on activity, the enzyme was preincubated with an inhibitor solution for 60 minutes at $4^{\circ} \mathrm{C}$ after which the remaining activity was tested

Reactivation of protease activity after inhibition by EDTA was carried out in the presence of $\mathrm{Ca}, \mathrm{Mg}$ and $\mathrm{Zn}$ ions following dialysis of the preparation.

Analysis of fragment of the amino acid sequence of the purified enzymatic protein. Both the highly purified enzyme preparation and the protein band (approx. $99 \mathrm{kDa}$ ) excised from polyacrylamide gel were subjected to mass spectrometry analysis (IBB PAN). The protein concentration in the sample was $10 \mu \mathrm{g} / \mathrm{ml}$. A protein sample previously digested with trypsin was separated on a nanoAcquity UPLC (Ultra Performance LC) system and analyzed with an Orbitrap-based mass spectrometer.

All results presented in this paper in the form of numerical values are means from three independent repetitions. The mean error, reflecting maximal deviation of the results of measurements from the mean, did not exceed 5\%.

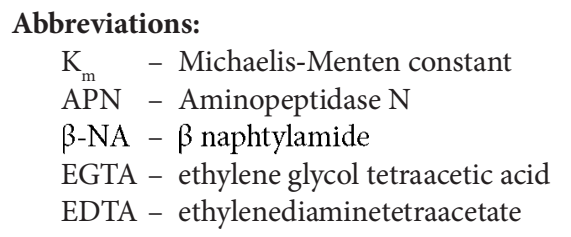

\section{Results}

The intracellular aminopeptidase synthesized by Pseudomonas putida Lup was purified over 150-fold in a four step procedure. The enzymatic activity of the enzyme during its purification and characterization was determined using A- $\beta$ NA as a substrate (Table I).

Table I

Purification of $P$. putida Lup aminopeptidase.

\begin{tabular}{|l|c|c|c|c|c|}
\hline \multicolumn{1}{|c|}{ Steps } & $\begin{array}{c}\text { Total } \\
\text { aminopeptidase } \\
\text { activity [U] }\end{array}$ & $\begin{array}{c}\text { Total } \\
\text { protein } \\
{[\mathrm{mg}]}\end{array}$ & $\begin{array}{c}\text { Specific } \\
\text { activity } \\
{[\mathrm{U} / \mathrm{mg}]}\end{array}$ & $\begin{array}{c}\text { Yield } \\
\text { Fold } \\
\text { purification } \\
{[\%]}\end{array}$ \\
\hline Crude enzyme & 10227.3 & 1605.6 & 6.4 & 1.0 & 100 \\
\hline Ammonium sulfate precipitation (35-85\%) & 8454.9 & 619.4 & 13.7 & 2.1 & 82.7 \\
\hline Ion-exchange chromatography cellulose DEAE 52 & 6715.4 & 186.6 & 36 & 5.6 & 65.7 \\
\hline Preparative electrophoresis & 2312.5 & 7.9 & 292.7 & 45.7 & 20.6 \\
\hline Ion-exchange chromatography HPLC Mono Q 8HR & 908.5 & 0.93 & 976.9 & 152.6 & 8.9 \\
\hline
\end{tabular}




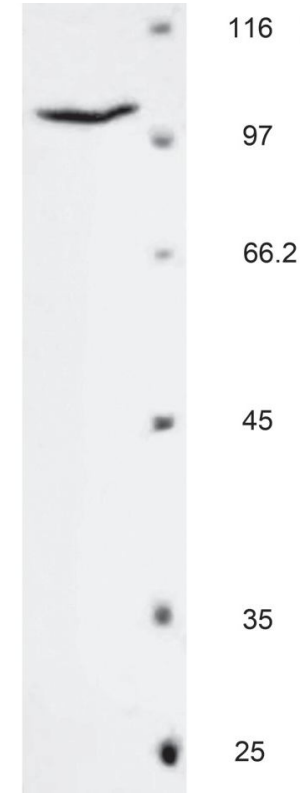

Fig. 1. SDS-PAGE of the purified aminopeptidase.

Salting out with ammonium sulfate and low pressure ion-exchange chromatography on DE $\Lambda$ E cellulose 52 resulted in a sample purified almost 6-fold with $65.7 \%$ recovery of total activity. Considerable, over 8 -fold purification of the enzyme was obtained after preparative electrophoresis. After the final step of purification, ion-exchange HPLC chromatography, over 150-fold purification of the enzyme was achieved. The molecular weight of the enzyme determined by SDS PAGE was approx. $99 \mathrm{kDa}$ (Fig. 1). This result was confirmed using molecular sieve chromatography, which determined a molecular weight of $98 \mathrm{kDa}$. This value shows that the studied enzyme is a monomer. Proteomic analysis of the purified enzymatic preparation using mass spectrometry (MS) demonstrated that the amino acid sequence of the studied enzymatic protein is highly similar to the sequence of the aminopeptidase $\mathrm{N}$ of Pseudomonas putida GB-1 (GenBank accession no. YP_001667790 which is identical to that translated from the nucleotide sequence of Gene ID: 58693290). The peptides derived from the studied aminopeptidase overlap with $45 \%$ of the aa sequence of aminopeptidase N from P.putida GB-1 (Fig. 2). High overlap of the obtained peptide sequence within the conserved domain of APN in Pseudomonas bacteria between amino acid residues 212 and 421 was determined. APN in strain GB-1 is composed of 885 amino acid residues. Its calculated molecular weight was $99.549 \mathrm{kDa}$ and the theoretical pI was 5.06 .

The purified P. putida Lup aminopeptidase has broad substrate specificity (Table II). The enzyme was shown to be active against the following amino acid derivatives of $\beta$-naphthylamide: $\Lambda-\beta-\mathrm{N} \Lambda$ (100\%), R- $\beta-\mathrm{N} \Lambda(60 \%)$, K- $\beta$-NA (25\%), L, S (10\%) and G, M- $\beta$-NA (5\%). The substrate affinity of $P$. putida lup aminopeptidase was determined for the substrates the enzyme had the highest activity against. Km constants determined did not show great variation, even though the lowest $\mathrm{K}_{\mathrm{m}}$ was obtained during enzymatic reaction against $A-\beta-N A$, which points to the highest affinity of the enzyme for this particular substrate. The effect of specific inhibitors on the activity of the studied enzyme was also examined (Table III). Partial inhibition of enzyme activity observed when inhibitors such as EDTA and

\begin{tabular}{|c|c|c|c|c|}
\hline & & & & \\
\hline DG & ASL & GDY & TLF & \\
\hline RIHPESNT & ALE & & $C D R$ & I \\
\hline$A \overline{E Q H R Y P V}$ & LLS & & & \\
\hline DTFTRQ & RIY & CD & & \\
\hline IVA & VNDE & & CVLA & \\
\hline JWS & GNR & ETV & 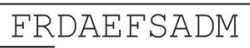 & \\
\hline QFA & EDAGP & PDSFIEISN & KG & $E V$ \\
\hline AEGFRKGS & DLYFERHDGQ & AVTTDDFIKA & EDF'I & QF'KRWYS \\
\hline RLEVSEAY & DAAAQAYSLT & FRQSCPQTPD & KAEF & VELC \\
\hline DLPLQLAGE & ATAQGTSI & SVTEAEQTET & FQRI & SLLRGF \\
\hline CLSFPYDRDQ & LMFLMQHDSD & GENRWEAGQQ & LSVQVLQELI & GQHQRGH \\
\hline 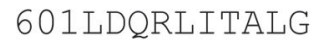 & 'I'VLGNE'SLDP & AMVAE'MLSLP & GE'AYL' & VADVDA $\perp$ \\
\hline FARQQIAE & QLFL & REVSRST & EYVASAEHE & RRSLQN \\
\hline MQSGKPQV & LEATLEQ & CDNMTERLTA & LAVLVNSPEE & AERAKALE \\
\hline LV & MDQW & GGLARV & KALMQHPAFT & LKNPNKVR \\
\hline ILV & HAAD & LV & NALNPQIASR & Dnt \\
\hline & & & & \\
\hline
\end{tabular}

Fig. 2. Sequence of aminopeptidase N from P. putida GB-1. 
Table II

Substrate preferences and affinity of purified P. putida Lup aminopeptidase.

\begin{tabular}{|l|c|c|}
\hline \multicolumn{1}{|c|}{ Substrate } & activity $(\%)$ & Km value $[\mathrm{M}]$ \\
\hline Ala- $\beta$-NA & 100 & $6.8 \times 10^{-5}$ \\
\hline Arg- $\beta$-NA g & 60 & $7.8 \times 10^{-5}$ \\
\hline Lys- $\beta$-NA & 25 & $7.5 \times 10^{-5}$ \\
\hline Leu- $\beta$-NA & 10 & nd \\
\hline Ser- $\beta$-NA & 10 & nd \\
\hline Gly- $\beta$-NA & 5 & nd \\
\hline Met & 5 & nd \\
\hline
\end{tabular}

Not-determined-nd

Table III

Effect of inhibitors on activity of $P$. putida Lup aminopeptidase.

\begin{tabular}{|l|c|c|}
\hline \multicolumn{1}{|c|}{ Inhibitor } & Concentration $(\mathrm{mM})$ & Activity $(\%)$ \\
\hline \multirow{2}{*}{ None } & - & 100 \\
\hline \multirow{2}{*}{ EDTA } & 1 & 85 \\
\cline { 2 - 3 } & 10 & 20 \\
\hline \multirow{2}{*}{ Iodoacetamide } & 1 & 70 \\
\cline { 2 - 3 } & 3 & 5 \\
\hline \multirow{2}{*}{ E-64 } & 0.5 & 60 \\
\cline { 2 - 3 } & 1 & 47 \\
\hline \multirow{2}{*}{ DFP } & 0.01 & 50 \\
\cline { 2 - 3 } & 0.1 & 40 \\
\hline Pepstatin A & 0.1 & 98 \\
\hline Bestatin & 1 & 96 \\
\hline Amastatin & 3 & 100 \\
\hline
\end{tabular}

1.10 phenanthroline were added to the reaction mixture, it indicates that the protein is a metallopeptidase. In this case partial reactivation of activity was obtained after adding $\mathrm{Co}^{2+}(20 \%)$ and $\mathrm{Zn}^{2+}$ ions (50\%). These results were confirmed in reaction with bestatin and
Table IV

Effect of metal ions and reducing agent on activity of P. putida Lup aminopeptidase.

\begin{tabular}{|c|c|c|}
\hline Metal ion & $\begin{array}{c}\text { Concentration } \\
(\mathrm{mM})\end{array}$ & $\begin{array}{c}\text { Relative Activity } \\
\text { (\%) }\end{array}$ \\
\hline None & - & 100 \\
\hline \multirow[t]{2}{*}{$\mathrm{Co}^{2+}$} & 0.1 & 120 \\
\hline & 1.0 & 140 \\
\hline \multirow[t]{2}{*}{$\mathrm{Ca}^{2+}$} & 0.1 & 120 \\
\hline & 1.0 & 130 \\
\hline \multirow[t]{2}{*}{$\mathrm{Mg}^{2+}$} & 0.1 & 115 \\
\hline & 1.0 & 130 \\
\hline \multirow[t]{2}{*}{$\mathrm{Zn}^{2+}$} & 0.1 & 10 \\
\hline & 1.0 & 0 \\
\hline \multirow[t]{2}{*}{$\mathrm{Pb}^{2+}$} & 0.1 & 15 \\
\hline & 1.0 & 10 \\
\hline \multirow[t]{2}{*}{$\mathrm{Cu}^{2+}$} & 0.1 & 65 \\
\hline & 1.0 & 18 \\
\hline \multirow[t]{2}{*}{$\mathrm{Mn}^{2+}$} & 0.1 & 95 \\
\hline & 1.0 & 85 \\
\hline \multirow{2}{*}{$\begin{array}{l}\text { Reduced glutathione } \\
(\mathrm{GSH})\end{array}$} & 0.1 & 120 \\
\hline & 1.0 & 180 \\
\hline \multirow[t]{2}{*}{ Dithioerythritol (DTE) } & 0.1 & 160 \\
\hline & 0.5 & 90 \\
\hline
\end{tabular}

amastatin, which are diagnostic inhibitors for metalloexopeptidases. However, inhibition of the enzyme was also demonstrated in the presence of cysteine protease inhibitors E64 and iodoacetamine. Moreover, after adding compounds counteracting the oxidation of - $\mathrm{SH}$ groups to the reaction mixture, such as reduced glutathione (GSH) or dithioerythritol (DTE), enhanced activity was observed, which is typical for cysteine enzymes (Table IV). Inhibitors specific for the remaining catalytic types of proteases (serine and aspartyl) did not cause any change in enzyme activity. The studied aminopeptidase was activated about $30-40 \%$ when $\mathrm{Ca}$,

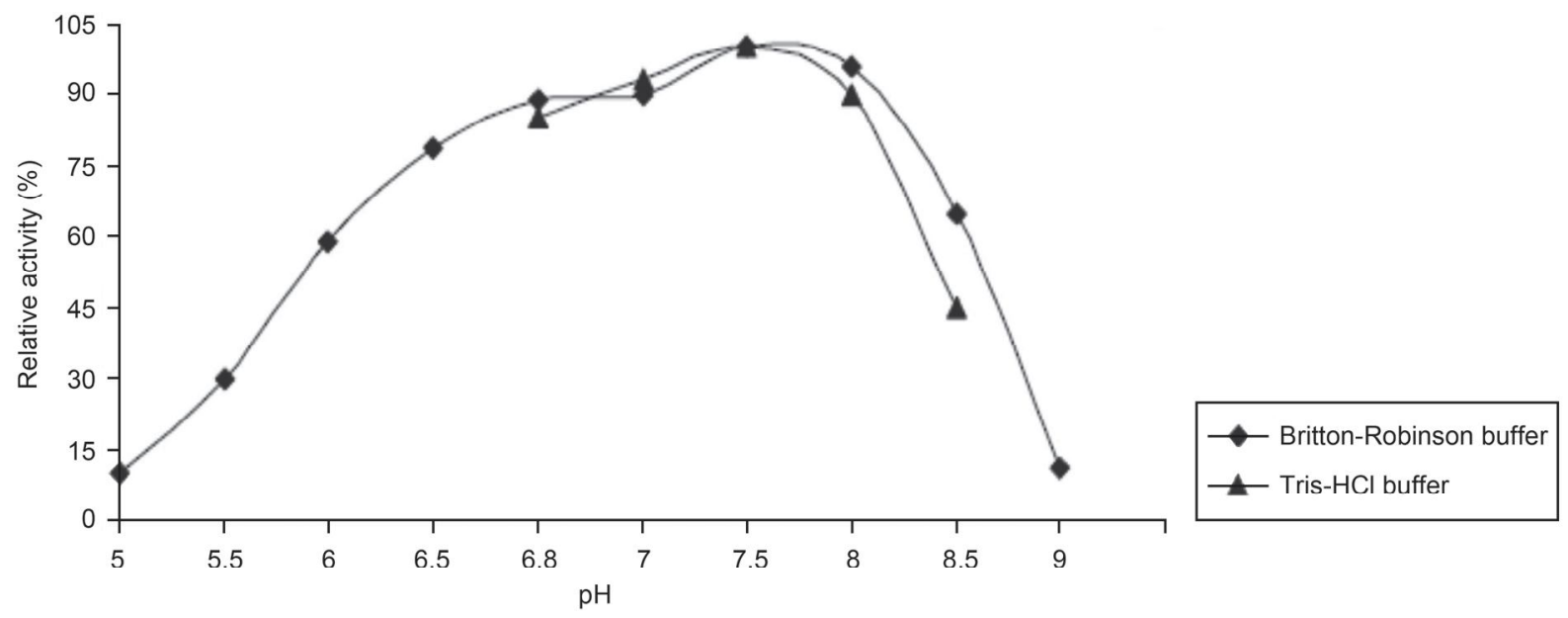

Fig. 3. Effect of pH on P. putida Lup aminopeptidase activity. 


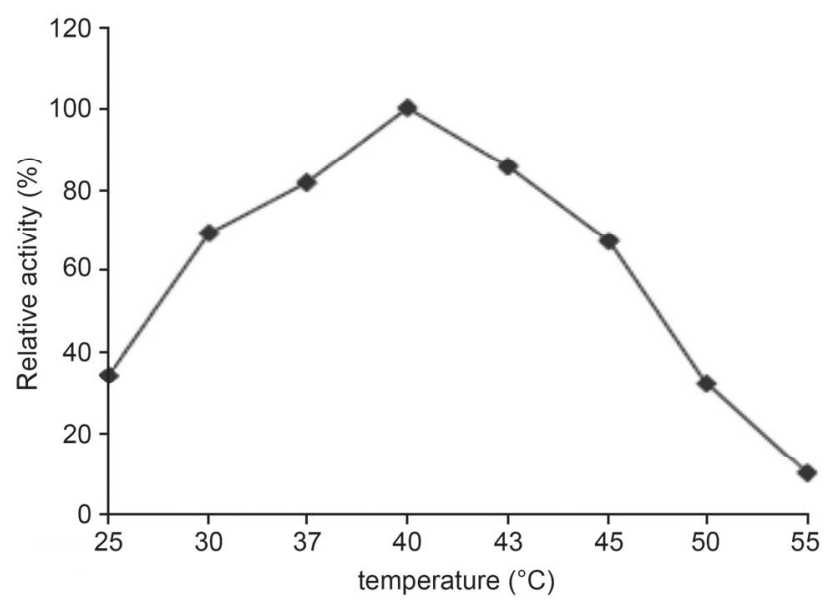

Fig. 4. Effect of temperature on P. putida Lup aminopeptidase activity. are in the fragment from residue 212 to 421 (Hooper, 1994). So far the best characterized ApN of Gram-negative bacteria are those from E. coli (Ito et al., 2006) and Neisseria meningitidis (Nocek et al., 2008). The structure of these proteins has been investigated using crystallography methods, providing detailed information regarding their active center and the spatial structure of their functional domains. In the APN molecule from E. coli, four domains have been distinguished: N-terminal $\beta$-domain $\mathrm{M}^{1}-\mathrm{D}^{193}$, catalytic domain: $\mathrm{F}^{194}-\mathrm{G}^{444}$, middle $\beta$-domain: $T^{445}-Y^{546}$ and $C$-terminal $\alpha$-domain: $S^{547}-A^{870}$ (Addlagatta et al., 2006). The similarity of the amino acid sequence of aminopeptidases $\mathrm{N}$ of E. coli and P.putida is slightly over $50 \%$.

There is far less information about the $\mathrm{ApN}$ of Pseudomonas sp. In case of P. putida ApN no detailed

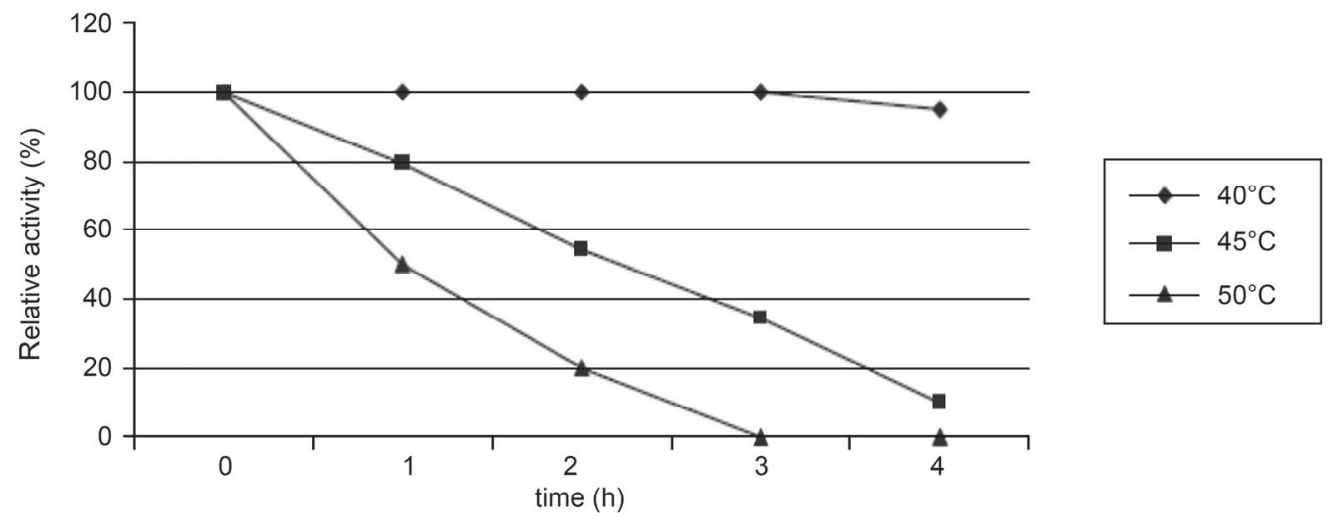

Fig. 5. Thermostability of $P$. putida Lup aminopeptidase at temperatures ranging from $40^{\circ} \mathrm{C}$ to $50^{\circ} \mathrm{C}$.

$\mathrm{Mg}$ and Co ions in concentration $1.0 \mathrm{mM}$ were added to them in the incubation mixture. Partial inhibition of activity was observed after the addition of $\mathrm{Pb}$ and $\mathrm{Zn}$ ions in low, $0.1 \mathrm{mM}$ concentration (Table IV).

The temperature and $\mathrm{pH}$ optima determined for $\Lambda-\beta N A$ were $40^{\circ} \mathrm{C}$ and $\mathrm{pH} 7.5$, respectively. The studied aminopeptidase demonstrated high activity in a broad $\mathrm{pH}$ range from 6.0 to 8.5 (Fig. 3). On the other hand, the activity of the enzyme was strongly dependent on temperature and slight deviations from the optimal temperature resulted in its significant decrease (Fig. 4). The studied aminopeptidase was characterized by high thermal stability after $240 \mathrm{~min}$ preincubation at $40^{\circ} \mathrm{C}$ (Fig. 5). Preincubation for the same length of time at $45^{\circ} \mathrm{C}$ resulted in almost complete loss of activity.

\section{Discussion}

APN produced by P.putida belong to family M1, subfamily M01 and has been given the number 005 . The conserved domain for family M1 stretches from amino acid residue 15 to 384 , conserved residues for aminopeptidase N of Gram-negative bacteria - M01.005 biochemical characterization of the enzyme has yet been conducted.

The aminopeptidase studied by our group has similar substrate specificity, except that its activity is the highest when the amino acid residue at the $\mathrm{N}$-terminus of the protein substrate is alanine, and not arginine, like for the E. coli $\Lambda \mathrm{pN}$. The substrate specificity of the E. coli ApN for $\mathrm{N}$-terminal amino acids can be arranged as follows: $A>R>K>P / G$ (Addlagatta et al., 2008). $A$ somewhat different substrate specificity was found for aminopeptidase $\mathrm{N}$ of Streptococcus thermophilus A. The enzyme demonstrated highest activity towards the following substrates: K-AMC: $100 \%>\mathrm{L} 93 \%>\mathrm{R}$ : $80>$ M: 28\% > A: 20\% (Chavagnat et al., 1999). Similar results were obtained also for S. thermophilus YRC001. For this reason the aminopeptidase $\mathrm{N}$ of these bacteria have been termed lysyl aminopeptidase (Motoshima et al., 2003). On the other hand, the N-like aminopeptidase of Lactobacillus curvatus DPC2024 showed highest activity with protein substrates carrying N-terminal L (100\%), K (63\%), F (58\%), M (26\%) and A (6\%) (Abdallah et al., 1999). Studies on the APN of E. coli K12 have revealed that it is a metallopeptidase but a thiol group of a cysteine is also involved in catalysis 
(Yoshimoto et al., 1988). However, it has not yet been determined which of the 8 cysteine residues present in the APN sequence plays a crucial role for the activity of the enzyme (Nocek et al., 2008). It cannot be excluded that the binding of the inhibitor to one of the cysteine residues located close to the active site of APN results in distortion of its structure and changes in the conformation of the protein molecule. A similar phenomenon is observed for the studied ApN from P. putida lup. The enzyme is strongly inhibited by specific inhibitors of cysteine enzymes and metallopeptidases. Stimulation of enzyme activity in the presence of reducing compounds confirms the importance of the -SH groups of cysteine in enzymatic catalysis or in maintaining the proper conformation of the enzyme molecule. The amino acid sequence of the P.putida APN contains amino acids residues involved in the binding of zinc ions: H 303, H 307 and E 326. The significant role of zinc ions in catalysis is also supported by the partial reactivation by these ions of the studied aminopeptidase previously treated with EDTA. The studied aminopeptidase was activated in the presence of Co ions and to a somewhat lesser degree by $\mathrm{Ca}$ and $\mathrm{Mg}$. A similar dependence was observed for the PepN-like enzyme in Lb. curvatus DPC2024 (Abdallah et al., 1999). Activation by Co ions has also been described for aminopetidase N S. thermophilus YRC001 aminopeptidase (Motoshima et al., 2003).

The molecular mass of the studied enzyme determined by SDS PAGE is about $99 \mathrm{kDa}$. A similar molecular mass calculated based on the amino acid sequence of the genes coding the enzymes is given for other P. putida aminopeptidases N. Aminopeptidases N with similar molecular masses have also been found in E. coli K 12: $87 \mathrm{kDa}$ (McCaman, and Villarejo, 1982) and Streptococcus thermophilus YRC001: $96.4 \mathrm{kDa}$ (Motoshima et al., 2003). The $\mathrm{pH}$ and temperature optima for the studied enzyme are 7.5 and $40^{\circ} \mathrm{C}$, respectively. APN of $S$. thermophilus A shows optimal activity under similar conditions: $\mathrm{pH} 7.0$ and $37^{\circ} \mathrm{C}$ (Chavagnat et al., 1999). Similarly, the N-like aminopeptidase of $L b$. curvatus demonstrates optimal activity at $\mathrm{pH} 7.0$ and $40^{\circ} \mathrm{C}$ (Christensen et al.,1999)

\section{Literature}

Abdallah A., A., Magboul and P.L.H. McSweeney. 1999. Purification and characterization of an aminopeptidase from Lactobacillus curvatus DPC2024. Inter. Dairy J. 9: 107-116.

Addlagatta A., L. Gay and B.W. Matthews. 2008. Structural basis for the unusual specificity of Escherichia coli aminopeptidase N. Biochemistry 47: 5303-5311.

Addlagatta A., L. Gay and W.B. Matthews. 2006. Structure of aminopeptidase N from Escherichia coli suggests a compartmentalized, gated active site. PNAS 36: 13339-13344.
Bradford M.M. 1976. A rapid and sensitive method for the quantization of microgram quantities of protein utilizing the principle of protein-dye binding. Anal. Biochem. 72, 248-254.

Chandu D. and D. Nandi. 2003. PepN is the major aminopeptidase in Escherichia coli: insights on substrate specificity and role during sodium-salicylate-induced stress. Microbiol. 149: 3437-3447.

Chandu D., A. Kumar A. and D. Nandi. 2003. PepN, the major Suc-LLVY-AMC-hydrolyzing enzyme in Escherichia coli, displays functional similarity with downstream processing enzymes in Archaea and eukarya. Implications in cytosolic protein degradation. J. Biol. Chem. 8: 5548-56.

Chavagnat F., M.G. Casey and J. Meyer. 1999. Purification, Characterization, Gene Cloning, Sequencing, and Overexpression of Aminopeptidase N from Streptococcus thermophilus A. Appl. Environ. Microbiol. 65: 3001-3007.

Holt J.G., N.R. Krieg, P.H.A. Sneath, J.T. Staley and S.T. Williams. 1994. Bergey's Manual of Determinative Bacteriology, $9^{\text {th }}$ edn., Baltimore, Williams and Wilkins press.

Hooper N.M. 1994. Families of zinc metalloproteases FEBS Lett. 31: 1-6.

Ito K., Y. Nakajima, Y. Onohara, M. Takeo, K. Nakashima, F. Matsubara, T. Ito and T. Yoshimoto. 2006. Crystal structure of aminopeptidase N (proteobacteria alanyl aminopeptidase) from Escherichia coli and conformational change of methionine 260 involved in substrate recognition. J. Biol. Chem. 44: 33664-3376.

Jankiewicz U. and W. Bielawski. 2003. The properties and functions of bacterial aminopeptidases. Acta Microbiol. Pol. 52: 217-231. King E.O., M.K. Ward and D.E. Raney. 1954. Two simple media for the demonstration of pyocyanin and fluorescin. J. Lab. Clin. Med. 44: 301-308

Kumar, M. Bhosale, S. Reddy, N. Srinivasan and D. Nandi. 2009. Importance of non-conserved distal carboxyl terminal amino acids in two peptidases belonging to the M1 family: Thermoplasma acidophilum Tricorn interacting factor F2 and Escherichia coli Peptidase N. Biochimie 91: 1145-1155.

Laemmli U.K. 1970. Cleavage of structural proteins during the assembly of the head of bacteriophage T4. Nature 227: 680-685.

Lazdunski C., J. Busuttil and A. Lazdunski. 1975. Purification and Properties of a Periplasmic Aminopendopeptidase from Escherichia coli. Eur. J. Biochem. 60: 363-369.

Matthews B.W. 1988. Structural basis of the action of thermolysin and related zinc peptidases. Acc. Chem. Re. 21:333-340.

McCaman M.T. and M. R. Villarejo. 1982. Structural and catalytic properties of peptidase N from Escherichia coli K-12. Arch. Biochem. Biop hys. 213: 384-394.

Motoshima H., T. Shiraishi, F. Tsukasaki and S. Kaminogawa. 2003. Purification, characterization, and gene cloning of lysyl aminopeptidase from Streptococcus thermophilus YRC001. Bio. Biotech. Biochem. 67: 772-782.

Nocek B., R. Mulligan, M. Bargassa, F. Collart and A. Joachimiak. 2008. Crystal structure of aminopeptidase $\mathrm{N}$ from human pathogen Neisseria meningitidis. Proteins. 70: 273-279.

Peer W.A. 2011. The role of multifunctional M1 metallopeptidases in cell cycle progression. Annals. of Botany 107: 1171-1181.

Rawlings N.D. and A.J. Barrett. 1993. Evolutionary families of peptidases. Biochem. J. 290: 205-218.

Watanabe K., Y. Kodama and S. Harayama. 2001. Design and evaluation of PCR primers to amplify bacterial $16 \mathrm{~S}$ ribosomal DNA fragments used for community fingerprinting. J. Microbiol. Methods. 44: 253-257.

Yoshimoto T., Y. Tamesa, K. Gushi, N. Murayama and D. Tsuru. 1988. An aminopeptidase N from Escherichia coli HB1010: purification and demonstration that the enzyme possesses arylamidase and peptidase activities. Agric. Biol. Chem. 52: 217-225. 